\title{
Differences in mineral concentrations on hooves of horses, mules and donkeys*
}

\section{Diferenças nas concentrações de minerais nos cascos de equinos, muares e asininos}

\author{
Anderson Fernando de Souza, ${ }^{* *}$ Jackson Schade, ${ }^{* * *}$ Rogério Laus, ${ }^{* * * *}$ Marcelo Alves Moreira, ${ }^{* * * *}$ \\ Thiago Rinaldi Muller, ${ }^{* * \star * *}$ Joandes Henrique Fonteque ${ }^{* * * *}$
}

\begin{abstract}
This study aimed to measure the concentrations of minerals in different regions and pigmentation of horses' hooves, mules and donkeys. A total of 20 Crioulo horses, 20 mules and 20 Pega donkeys were used. They formed two groups: pigmented (dark) or non-pigmented (bright) hooves. All animals were unshod and with adequate foot conformation. Females were nonpregnant and without foal and no animals were in training. Samples were collected from the hooves of all limbs in the regions of wall, sole and frog. The concentrations of calcium, magnesium, copper, iron and zinc were determined by atomic absorption spectrophotometry; sodium and potassium concentrations were determined by atomic emission spectrophotometry. Among the groups it was observed that the wall, sole and frog of donkeys' hooves presented higher concentrations of sodium and calcium and with the exception of the frog that also obtained higher levels of copper in this species. Mules had lower concentrations of zinc in the wall and the horses had higher concentrations of potassium and zinc in the sole and higher magnesium in the frog and wall. There was no difference $(P>0.05)$ in concentrations regarding the pigmentation of the hooves. The different regions of the hooves in each group presented similar concentrations of minerals and it was regardless of the pigmentation. The mineral concentrations may be related to desirable functional properties of the donkeys' hooves. Pigmented and non-pigmented hooves have similar concentrations of minerals.
\end{abstract}

Keywords: Podiatry, equids, trimming, chemical elements.

\section{Resumo}

O objetivo desse trabalho foi mensurar os teores de minerais nas diferentes regiões e pigmentações dos cascos de equinos, muares e asininos. Utilizaram-se 20 equinos da raça Crioula, 20 muares e 20 asininos da raça Pêga. Formaram-se dois grupos conforme os cascos pigmentados (escuros) e não pigmentados (claros). Todos os animais estavam desferrados e com adequada conformação podal e as fêmeas estavam não gestantes e sem potro ao pé e nenhum animal estava em treinamento. Amostras foram coletadas dos cascos de todos os membros nas regiões de parede, sola e ranilha. As concentrações de cálcio, magnésio, cobre, ferro e zinco foram determinadas por espectrofotometria de absorção atômica e as concentrações de sódio e potássio foram determinadas por espectrofotometria de emissão atômica. Entre os grupos observou-se que a parede, sola e ranilha nos asininos apresentaram maiores valores de sódio e cálcio e, exceto para a ranilha, também obteve-se maiores teores de cobre nesta espécie. Os muares apresentaram menores teores de zinco na parede e, os equinos, maiores teores de potássio e zinco na sola e ranilha e de magnésio na ranilha e parede. Não houve diferença $(P>0,05)$ nos teores dos minerais quanto à pigmentação dos cascos. As diferentes regiões dos cascos em cada grupo apresentaram teores similares de minerais e este independeu da pigmentação. As variações dos teores de minerais entre os grupos podem estar relacionados a propriedades funcionais desejáveis dos cascos dos asininos. Cascos pigmentados e não pigmentados apresentam teores similares dos minerais.

Palavras-chave: Podologia, equídeos, casqueamento, elementos químicos.

*Recebido em 28 de outubro de 2017 e aceito em 15 de outubro de 2019.

**Aluno de Graduação, Centro de Ciências Agroveterinárias (CAV), Universidade do Estado de Santa Catarina (UDESC), Lages, SC, Brasil.

***Aluno do Programa de Pós Graduação em Ciência Animal, Centro de Ciências Agroveterinárias (CAV), Universidade do Estado de Santa Catarina (UDESC), Lages, SC, Brasil.

****Departamento de Solos e Recursos Naturais, Centro de Ciências Agroveterinárias (CAV), Universidade do Estado de Santa Catarina (UDESC), Lages, SC, Brasil.

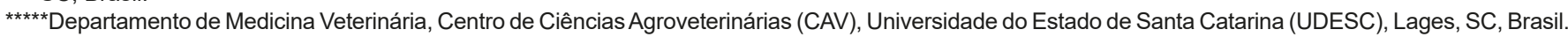




\section{Introduction}

Equine hooves provides a solid foundation for mobility with agility and high speed and are intimately balanced with the environment they are adapted (Davies et al., 2007; Kainer and Fails, 2011). The different species that make up the genus Equus have divergent genetic, physiological, anatomical, environmental and evolutionary characteristics among each other. This caracteristics are strong influencers of morphologic and functional properties of the hoof, showing specific hoof conformation, which should be studied in detail (Janis and Bernor, 2019, Souza et al, 2016).

Physical demands on the equids often exposes the hoof to its functional limit, affecting its properties. Thus, the generation and application of knowledge to fix the problems generated is a duty of the professionals involved (Reilly, 1998). The statements of Budras and Schiel (1996) contributes to this by observations of the white line quality of wild Przewalski horses, which showed that they were in better condition than those observed in domesticated horses. The quality of the hoof is influenced by several factors, among them age, breed, genetics, metabolism, training, environment, trimming, disease and nutrition, as an appropriate source of energy, protein, vitamins and minerals leads to adequate hoof growth (Huntington and Pollitt, 2005). Several studies have been conducted to assess whether supplementing with vitamins, minerals and amino acids may improve the quality of the hoof (Comben et al., 1983; Josseck et al., 1995; Ott and Johnson, 2001). Regarding minerals, zinc and copper receive emphasis on improving the hoof quality and little focus was given to other minerals needed for metabolism.

Studies have been conducted to investigate the chemical composition of horses and donkeys hooves, but there are still few and not enough to help in the indication of strategies that improve the quality of the hooves of the animals (Faria et al., 2005; Sargentini et al., 2012; Tocci et al., 2015). Thus, this study aimed to determine and compare the concentrations of sodium, potassium, copper, iron, zinc, magnesium and calcium in different regions of the hoof and between pigmented and non-pigmented hooves of horses, mules and donkeys.

\section{Material and methods}

\section{Animals}

The animal use met the requirements of the Santa Catarina State University Animal Ethics Committee ( $n^{\circ}$ 01.05.13). Animal owners gave consent for their inclusion in the study.

The animals used $(n=60)$ are from farms located in the cities of Mafra, Campo Alegre and Lages, in the state of Santa Catarina, Brazil. They were allocated into three groups: G1: 20 horses of Crioulo breed with an average age of $8.3 \pm 5.0$ years and average weight of $425.32 \pm 45.47 \mathrm{~kg}$, being 13 females $(65 \%)$ and seven males (35\%); G2: 20 mules (originated from crosses between donkeys of Pega breed with mares of the Thoroughbred or Mangalarga Marchador breed), with a mean age of $6.2 \pm 2.3$ years and average weight of $284.82 \pm 31.20 \mathrm{~kg}$, being 15 females (75\%) and five males (25\%); and G3: 20 donkeys Pega breed with an average age of $8.7 \pm 8.5$ years and average weight of $218.97 \pm 37.83 \mathrm{~kg}$, being 12 females $(60 \%)$ and eight males (40\%). They formed two groups according to pigmented (dark) and non-pigmented (bright) hooves. Animals with striped hooves were not included. All animals were unshod and with adequate foot conformation. Females were empty and without foal and no animals were in training. All animals were managed in semi extensive breeding system, fed with natural pasture, ryegrass (Lolium multiflorum Lam.) hay of the Tifton 85, mineral salt, commercial concentrate diet (14\% crude protein) according to the manufacturer's recommendations and water ad libitum.

\section{Data collection and parameters observed}

Sampling was conducted during the summer of 2013 and 2014. Samples of the hooves of fore and hindlimbs were collected from regions the wall, sole and frog with the aid of a hoof nipper and hoof knife. Then washed with mineral-free detergent and distilled water, dried with absolute alcohol and packed in labeled plastic bags, sealed and frozen until the time of analysis. The amount of $0.3 \mathrm{~g}$ of each sample was digested in $6.0 \mathrm{~mL}$ of concentrated $\mathrm{HNO}_{3}$ solution in digester microwave Multiwave 300 (PerkinElmer, Billerica, Massachusetts, United States), after completing to 100 fold prior dilution with distilled water with a conductivity lower than $5 \mu \mathrm{S} / \mathrm{cm}$ measured with a digital conductivity type portable pen being placed in conical tubes of $50 \mathrm{~mL}$, kept under refrigeration.

The concentrations of calcium, magnesium, copper, iron and zinc were determined in a flame atomic absorption spectrophotometer model AAnalyst 200 (PerkinElmer, Billerica, Massachusetts, United States) and the sodium and potassium concentrations were determined on a flame atomic emission spectrophotometer model DM-62 (Digimed, Campo Grande, MS, Brazil). The standard solutions of these elements were prepared from the dilution polyethylene vials (Sigma-Aldrich Brazil Ltda.) containing the salts of metal ions. A lanthanum solution $1.0 \%$ was added to standard calcium solution to complex the phosphorus and let that free element for analysis (Tedesco et al., 1995).

\section{Statistical analysis}

Inclusion of animals followed a non-probability convenience sampling and the statistical analysis performed by analysis of variance (ANOVA) followed by Tukey's test to compare the averages of minerals from different regions of the hoof within each group and the same region between groups. The Student $t$ test was used for comparisons between pigmented and non-pigmented hooves to the same region within each group, assuming a probability of error of $5 \%$.

\section{Results}

Mean values and standard deviations for the concentrations of copper, iron, sodium, potassium, zinc, calcium and magnesium, expressed in ppm, to the hoof wall, sole and frog of the horses, mules and donkeys of all hooves and between hooves pigmented and not pigmented are shown in Tables 1, 2 and 3, respectively.

The comparisons of the same region of the hoof between groups, regardless the color (Table 1$)$ revealed that the wall $(P<0.0001)$, sole $(P=0.0011)$ and frog $(P=0.0009)$ of the hooves of donkeys had higher sodium values and, except for the frog, higher cooper concentrations were also obtained ( $P<0.0001$ for both). Calcium concentrations were higher on the wall $(P=0.0088)$ and frog $(P<0.0001)$ in this species. Mules had lower concentrations of zinc in the wall $(P<0.0001)$ and horses presented higher potassium and zinc concentrations in the sole $(P=0.0492$ and 
Table 1: Concentrations of different minerals on the wall, sole and the frog of the hooves regardless of its pigmentation, in the horse $(n=20)$, mules $(n=20)$ and donkeys $(n=20)$

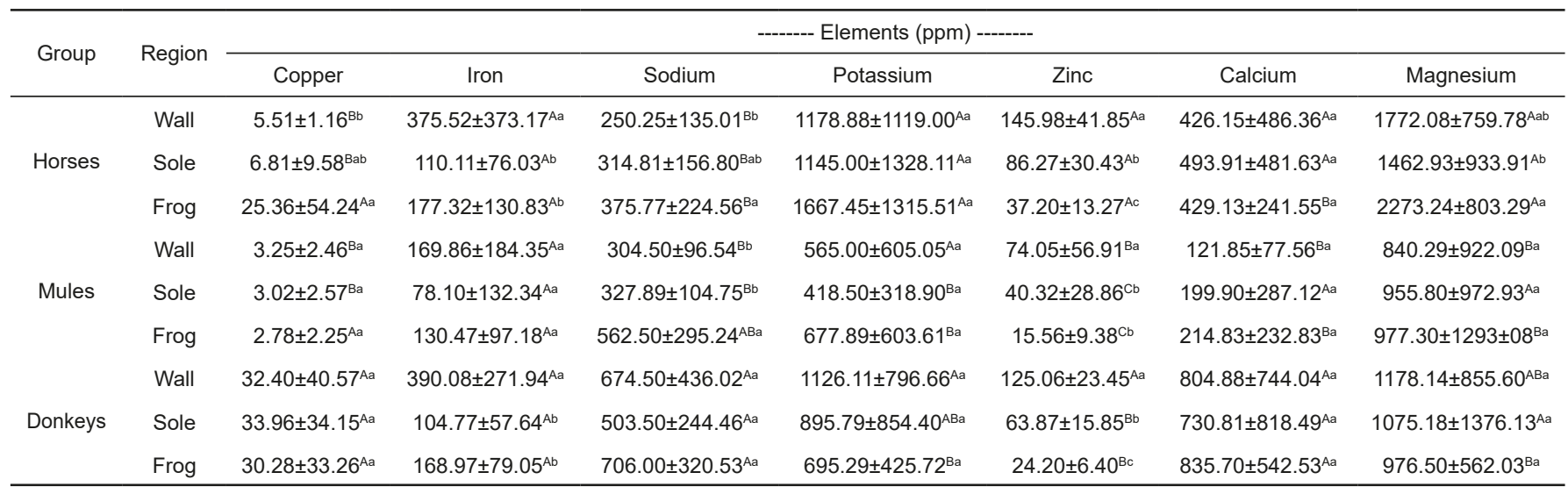

In the column, values followed by different capital letters for the same region in the between groups and different lower letter to different regions in the same group, disagree from each other $(P<0.05)$

Table 2: Concentrations of different minerals on the wall, sole and the frog of pigmented hooves (dark) in the horse, mules and donkeys. $(n=?)$

\begin{tabular}{|c|c|c|c|c|c|c|c|c|}
\hline \multirow{2}{*}{ Group } & \multirow{2}{*}{ Region } & \multicolumn{7}{|c|}{------- Elements (ppm) -------- } \\
\hline & & Copper & Iron & Sodium & Potassium & Zinc & Calcium & Magnesium \\
\hline \multirow{2}{*}{ Horses } & Wall & $5.41 \pm 0.90^{\mathrm{Bab}}$ & $413.80 \pm 404.94^{\mathrm{Aa}}$ & $267.45 \pm 115.26^{\mathrm{Ba}}$ & $1189.33 \pm 1102.64^{\mathrm{Aa}}$ & $144.61 \pm 43.16^{\mathrm{Aa}}$ & $393.14 \pm 528.85^{\text {АВа }}$ & $1807.01 \pm 648.27^{\mathrm{Aa}}$ \\
\hline & Frog & $50.18 \pm 79.95^{\mathrm{Aa}}$ & $224.65 \pm 170.34^{\mathrm{Aa}}$ & $295.49 \pm 140.23^{\mathrm{Ba}}$ & $1608.98 \pm 1102.56^{\mathrm{Aa}}$ & $41.19 \pm 16.15^{\mathrm{Ac}}$ & $479.03 \pm 320.30^{\text {АВа }}$ & $2396.53 \pm 1012.06^{\mathrm{Aa}}$ \\
\hline \multirow{2}{*}{ Mules } & Wall & $3.75 \pm 2.49^{\mathrm{Ba}}$ & $221.66 \pm 198.18^{\mathrm{Aa}}$ & $311.33 \pm 105.08^{\mathrm{Bb}}$ & $582.67 \pm 687.85^{\mathrm{Aa}}$ & $76.99 \pm 55.12^{\mathrm{Ba}}$ & $122.38 \pm 61.95^{\mathrm{Ba}}$ & $945.23 \pm 978.10^{\mathrm{Ba}}$ \\
\hline & Frog & $3.25 \pm 2.33^{\mathrm{Ba}}$ & $154.32 \pm 98.83^{\mathrm{Aa}}$ & $574.67 \pm 331.14^{\text {Aa }}$ & $730.67 \pm 663.92^{\mathrm{Ba}}$ & $15.54 \pm 7.93^{\text {в }}$ & $202.10 \pm 212.55^{\text {ва }}$ & $1208.29 \pm 1386.56^{\mathrm{ABa}}$ \\
\hline \multirow{3}{*}{ Donkeys } & Wall & $34.56 \pm 43.28^{\mathrm{Aa}}$ & $413.84 \pm 295.29^{\mathrm{Aa}}$ & $585.00 \pm 296.29^{\mathrm{Aa}}$ & $1018.00 \pm 584.38^{\text {Аa }}$ & $126.43 \pm 23.43^{\mathrm{Aa}}$ & $873.20 \pm 826.98^{\mathrm{Ab}}$ & $1114.48 \pm 946.68^{\text {АВа }}$ \\
\hline & Sole & $8.65 \pm 4.45^{\mathrm{Aa}}$ & $127.40 \pm 85.98^{\mathrm{Aa}}$ & $480.00 \pm 183.85^{\mathrm{Aa}}$ & $1450.00 \pm 1668.77^{\text {Аa }}$ & $46.50 \pm 5.09^{\mathrm{Ab}}$ & $2605.33^{\text {Aa* }}$ & $-* *$ \\
\hline & Frog & $28.08 \pm 33.66^{\mathrm{ABa}}$ & $186.43 \pm 90.98^{\mathrm{Aa}}$ & $652.31 \pm 254.30^{\mathrm{Aa}}$ & $725.45 \pm 473.29^{\mathrm{Ba}}$ & $23.73 \pm 4.69^{\mathrm{Bb}}$ & $819.67 \pm 416.97^{\mathrm{Ab}}$ & $969.45 \pm 651.66^{\mathrm{Ba}}$ \\
\hline
\end{tabular}

In the column, values followed by different capital letters for the same region in the between groups and different lower letter to different regions in the same group, disagree from each other $(\mathrm{P}<0.05){ }^{*}$ There was only one repetition. ${ }^{* *}$ There were no repetitions for this variable.

Table 3: Concentrations of different minerals on the wall, sole and the frog of non-pigmented hooves (bright) in the horse, mules and donkeys. $(n=$ ?)

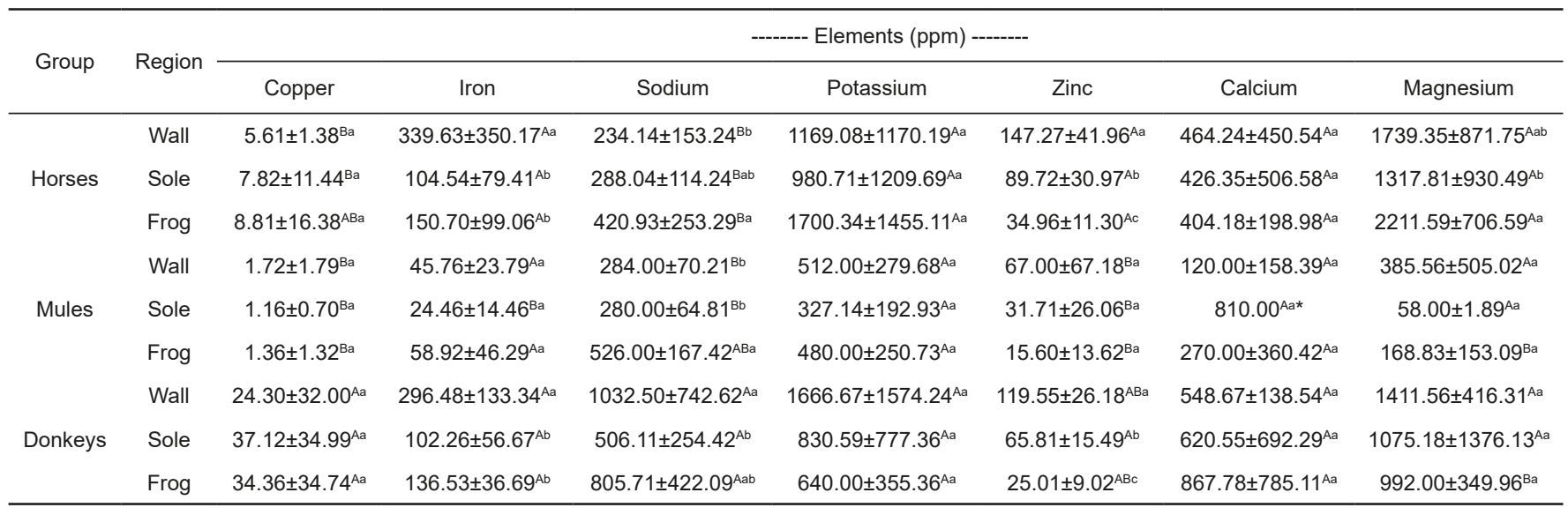

In the column, values followed by different capital letters for the same region in the between groups and different lower letter to different regions in the same group, disagree from each other $(P<0.05)$. ${ }^{*}$ There was only one repetition. 
0.0008 respectively) and frog $(P<0.0001$ for both $)$ and higher magnesium in the frog $(P<0.0001)$ and wall $(P=0.0015)$.

Comparing the different regions of the hoof, within a group, regardless of the color (Table 1 ) were observed higher concentrations of copper $(P=0.0353)$, sodium $(P=0.0298)$ and magnesium $(P=0.0033)$ and lower zinc concentration $(P<0.0001)$ in the frog. For the wall of the hooves of horses were observed higher iron concentrations $(P=0.0002$. The mules showed higher sodium concentrations $(P<0.0001)$ and zinc $(P<0.0001)$ for the frog and the wall, respectively. The donkeys had higher iron concentration $(P<0.0001)$ and zinc $(P<0.0001)$ in the wall of the hoof.

Assessing only the pigmented hooves (Table 2) for the same region of the hoof between the groups it was observed that, in relation of the hooves' wall, donkeys had a higher copper $(P=0.0021)$ and sodium $(P<0.0001)$ concentration; mules presented lower concentrations of zinc $(P=0.0004)$ and calcium $(P=0.0267)$ and horses had higher concentration of magnesium $(P=0.0270)$. For soles, results showed that copper $(P=0.0631)$ and calcium $(P<0.0001)$ concentrations had higher values in donkeys. Concerning the frog, it was observed a larger amount of copper $(P=0.0449)$, potassium $(P=0.0179)$, zinc $(P<0.0001)$ and magnesium $(P=0.0224)$ and lower sodium $(P=0.0130)$ in horses and mules presented lower calcium concentrations.

In non-pigmented hooves (Table 3 ) it was also evaluated the same region of the hoof between the groups and it was observed that, in relation of the hooves' wall, the results showed greater concentrations of copper on the whole hoof donkeys' and lower zinc concentrations on the whole hoof mules'. The sole of donkeys showed higher sodium $(P=0.0017)$ and mules have lower iron $(P=0.0175)$. Regarding the frog, magnesium $(P<0.0001)$ were higher in horses.

Evaluating minerals concentrations from different regions of the hoof in each group, it was observed that compared to pigmented (Table 2), the frog of horses $(P=0.0355)$ and mules $(P=0.0045)$ showed higher concentrations of copper and sodium, respectively. The donkeys' hoof wall showed higher concentrations of calcium; zinc was the mineral with higher concentration between elements to the hooves wall of all the groups $(P<0.0001)$. Regarding the non-pigmented hooves (Table 3 ), the wall of the hooves of horses and donkeys had higher zinc concentrations $(P<0.0001$, in both $)$ and copper $(P=0.0058$ and $\mathrm{P}<0.0001$, respectively). The sodium had higher concentrations in the frog of horses $(P=0.0157)$ and mules $(P=0.0026)$ and the wall of donkeys $(P=0.0348)$; magnesium showed the highest concentration in the frog of horses $(P=0.0134)$ and iron has higher in wall of the horses and donkeys.

Statistical evaluation, comparing pigmented and non-pigmented hooves, within each group, did not show significant differences to the same regions on the hooves of horses. The mules obtained higher copper concentrations in the pigmented sole.

\section{Discussion}

The average concentrations of some elements presented certain deviation from the published data, which also varied for each other (Tocci et al., 2015; Sargentini et al., 2012; Faria et al., 2005). This difference may be associated with the methodology used in each experiment, associated with variables that influence the quality of the hoof. In the present study there were differences in the concentrations of the minerals in practically all comparisons, except between the colorations within each group.

The hooves of donkeys are assigned various qualities such as wear resistance, better adaptation in higher impact surface and the low occurrence of foot problems. These aspects are related conformation features such as the wall thickness of the shell, being relatively constant throughout the wall (Reilly, 1997), the thicker sole and the structural composition of the hoof wall featuring three tubular zones (Hopegood, 2002), tubules less density towards equine (Thiemann and Rickards, 2013). In addition to the above features, the differences in the concentrations of elements assessed can also be a contributing factor to the quality of the hooves in this species.

The zinc is an element that deserves more attention as it has been identified as one of the main mineral involved in catalytic steps, structural and regulatory process of keratinization (Smart and Cymbaluk, 1997; Kasapi and Gosline, 1999). It is present in the skin, hair, wool and its deficiency progress to parakeratosis, alopecia and deformity of the hoof (Pardo and Reis, 2008). The wall of the hooves of donkeys and unexpectedly of horses, showed the highest concentrations of this element, because due to genetic contribution, it was expected that the mules would be in an intermediate condition, which would explain a possible correlation between greater hooves strength of donkeys and mules and zinc concentration, which had not been shown.

The zinc also showed greater concentration on the wall in relation to other parts of the hooves in all groups. The same results were found by Tocci et al. (2015) where observed higher concentrations of zinc in the wall of the hooves of Anglo-Arabian horse and Monterufoli ponies compared to the sole. However, Sargentini et al. (2012) identified higher concentrations of zinc in the soles of the hooves of donkeys Amiata.

The higher copper concentrations observed mainly in the wall and soles of the hooves of donkeys, may explain the greater wear resistance compared to the other groups, because this element is associated with the activity of thiol oxidase enzyme, which is responsible for the formation of links disulfide between Cis residues of the keratin filaments (O'Dell, 1990). This process is essential for structural strength at the cellular level, providing rigidity to the matrix of keratinized cells (Tomlinson et al., 2004). The concentrations of this element were like those found in other studies (Faria et al., 2005; Sargentini et al., 2012; Tocci et al., 2015).

The combination of hardness with pigmentation always divides opinion. Since cooper is associated with the cover structure associated with both steps of the hoof keratin, as in the melanin synthesis (Pardo and Reis, 2008), which gives the pigment there might be a relationship between the dark pigmentation and hardness of the hoof. However, this assumption was not confirmed in this study, since this mineral concentration was similar in pigmented and non-pigmented colors.

There was no difference between any mineral element rated for the same region of the hoof, in the different colors within the same group. This finding suggests that the color has no influence on the quality of the hooves of horses, reinforcing the statements made by other authors (Landeau et al., 1983; Faria et al., 2005). Landeau et al. (1983) found no differences in the strength-pressure behavior and maximum strength properties of 
pigmented and non-pigmented hooves of horses. In assessing horses' hooves of Mangalarga and Pantaneiro, Faria et al. (2005) observed similar concentrations of amino acids in both hues of hoofs, concluding that the preference for one or another color is not justified.

Calcium also seems to contribute to the greater hardness of the hooves of donkeys, presenting higher concentrations in the wall of the hooves of this species. This element also has functions linked to keratinization process and activation of epidermal transglutaminase, which performs the cross connection of the cell envelope of keratin fibers. In addition, it is involved in the initiation and regulation of terminal differentiation of epidermal cells. This enzyme helps activate the final stage of keratinocyte production fully differentiated (Tomlinson et al., 2004).

The analysis by means of elementary components appears to be a shape that truly no reflects the physical-mechanical properties of the hoof, as the interactions between of the elements are many (Pardo and Reis, 2008). Higher concentrations of certain elements may not be key points for making inferences, as an element in a low concentration can be arranged to a chemical architecture and/or exert a specific metabolic function, which gives physical and structural properties much larger than the other element higher concentrations. Analysis of the amino acid profile shows a little more specific, but still does not

\section{References}

BUDRAS, K. D.; SCHIEL C. A comparison of horn quality of the white line in the domestic horse (Equus caballus) and the Przewalski horse (Equus przewalski). Pferdeheilkunde, v. 12, n. 4, p. 641-645, 1996.

COMBEN, N.; CLARK, R. J.; SUTHERLAND, D. J. Clinical observations on the response of equine hoof defects to dietary supplementation with biotin. Veterinary Record, v. 115, n. 25-26, p. $642-645,1983$.

DAVIES, H. M.; MERRITT, J.; THOMASON, J. Biomechanics of the equine foot. In: FLOYD, A. E.; MANSMANN, R. (eds). Equine Podiatry. Missouri: Saunders, 2007, p. 42-53.

FARIA, G. A.; REZENDE, A. S. C.; SAMPAIO, I. B. M. et al. Composição química dos cascos de equinos das raças Pantaneira e Mangalarga Marchador. Arquivo Brasileiro de Medicina Veterinária e Zootecnia, v. 57, n. 5, p. 697-701, 2005.

HOPEGOOD, L. Tubule density, moisture content and mechanical properties of donkey hoof horn. 2002. Thesis (PhD), De Montfort University, Leicester, 2002.

HUNTINGTON, P.; POLLITT, C. C. Nutrition and the equine foot. In: PAGAN, J. D., GEOR, R. J. (eds). Advances in Equine Nutrition III. Nottingham: University Press, 2005. p. 23-35.

JANIS, C. M.; BERNOR, R. the evolution of equid monodactyly: a review including a new hypothesis. Frontiers in Ecology and Evolution, v. 7, p. 119, 2019.

JOSSECK, H.; ZENKER, W.; GEYER, H. Hoof horn abnormalities in Lipizzaner horses and the effect of dietary biotin on macroscopic aspects of hoof horn quality. Equine Veterinary Journal, v. 27, n. 3, p. 175-182, 1995. provide enlightening information when taken in isolation. Both methods of studies are important for the awareness of these concentrations' parameters and the comparison between groups and to recognize the relationship that may be present in a greater wear resistance of the equids hooves.

Ley et al. (1998) evaluated the effect of the season and the diet, concluding that these factors show great influence in the contents of various minerals and in the resistance of horses' hooves. The present work sought to minimize the effect of these variables could exert on the evaluations, through the collection was concentrated in the summer season, besides that all the animals were kept in similar geoclimatic conditions and food management.

\section{Conclusion}

The variations of the mineral contents, mainly calcium and copper may be related to the most desirable functional properties of the donkey's hooves. As well as the higher concentrations of zinc in the wall in all circumstances evaluated, they demonstrate a probable structuring for better resistance of this portion to the impact/wear, but more objective methodologies should be used for better inference. Pigmented and non-pigmented hooves of horses, mules and donkeys have similar concentrations of minerals.

KAINER, R. A.; FAILS, A. D. Functional anatomy of the equine musculoskeletal system. In: BAXTER, G. M. (ed). Adams and Stashak's Lameness in Horses. 6. ed. Oxford: Blackwell, 2011. p. 3-72.

KASAPI, M. A.; GOSLINE, J. M. Micromechanics of the equine hoof wall: optimizing crack control and material stiffness through modulation of the properties of keratin. Journal of Experimental Biology, v. 202, n. 4, p. 377-391, 1999.

LANDEAU, L. J.; BARRETT, D. J.; BATTERMAN, S. C. Mechanical properties of equine hooves. American Journal of Veterinary Research, v. 44, n. 1, p. 100-102, 1983

LEY, W. B.; PLEASANT, R. S.; DUNNINGTON, E. A. Effects of season and diet on tensile strength and mineral content of the equine hoof wall. Equine Veterinary Journal, J. v. 30, suppl. 26, p. 46-50, 1998.

O'DELL, B. L. Copper. In: BROWN, M. L. (ed). Present Knowledge in Nutrition. 6. ed. Washington: International Life Sciences Institute Press, 1990. p. 261-267.

OTT, E. A.; JOHNSON E. L. Effect of trace mineral proteinates on growth and skeletal and hoof development in yearling horses. Journal of Equine Veterinary Science, v. 21, n. 6, p. 287-291, 2001.

PARDO, P. E., REIS, L. S. Nutrientes e nutracêuticos em grandes animais, In: ANDRADE, S. F. (ed). Manual de Terapêutica Veterinária. 3. ed. São Paulo: Roca, 2008. p. 808-823.

REILLY, J. D. The donkey's foot and its care, In: SVENDSEN, E. D. (ed). The Professional Handbook of the Donkey, 3. ed. London: Whittet Books, 1997. p. 70-92.

REILLY, J. D. Hail hoof science!. Equine Veterinary Journal, v. 30, suppl. 26, p. 2-3, 1998. 
SARGENTINI, C.; TOCCI, R.; ANDRENELLI, L.; GIORGETTI, A. Preliminary studies on hoof characteristics in Amiata donkey. Italian Journal of Animal Science, v. 11, n. 1, p. 123-127, 2012.

SMART, M.; CYMBALUK, N. F. Role of nutritional supplements in bovine lameness, In: GREENOUGH, P. R.; WEAVER, A. D. (eds). Lameness in Cattle, 3. ed. Philadelphia: Saunders, 1997. p. 145-161.

SOUZA, A. F.; KUNZ, J. R.; LAUS, R.; MOREIRA, M. A.; MULLER, T. R.; FONTEQUE, J.H. Biometrics of hoof balance in equids. Arquivo Brasileiro de Medicina Veterinária e Zootecnia, v. 68, n. 4, p. 825-831, 2016.

TEDESCO, M.J.; GIANELLO, C.; BISSANI, C.A. et al. Análise de solos, plantas e outros materiais. 2 ed. Porto Alegre, Universidade Federal do Rio Grande do Sul, 1995. 174p.
THIEMANN, A.; RICKARDS, K. Donkey hoof disorders and their treatment. In Practice, v. 35, n. 3, p. 134-140, 2013.

TOCCI, R.; SARGENTINI, C.; MARTINI, A.; GIORGETTI, A. Qualitative hoof characteristics in Anglo-arabian horses and Monterufoli Ponies reared in the same farm. Global Journal of Animal Scientific Research, v. 3, n. 1, p. 20-29, 2015.

TOMLINSON, D. J.; MÜLLING, C. H.; FAKLER, T. M. Invited review: formation of keratins in the bovine claw: roles of hormones, minerals, and vitamins in functional claw integrity. Journal of Dairy Science, v. 87, n. 4, p. 797-809, 2004. 